\title{
The Role of Music in Predicting Academic Achievement: A Technological Discovery
}

\author{
Patricio K. Chap-as ${ }^{1}$, Patrociño C. de Vera $\mathrm{II}^{2}$, Hernando L. Bernal ${ }^{3}$, Jr., Abigail ${ }^{4}$, Rancy \\ E. Balitar $^{5}$ \\ ${ }^{1}$ Schools Division of Baguio City, Irisan National High School \\ ${ }^{2}$ Schools Division of Baguio City, Irisan National High School- Senior High School \\ ${ }^{3}$ Far Eastern University - NRF \\ ${ }^{4}$ Schools Division of Baguio City, Quezon Hill Elementary School \\ 5 Division of Cavite \\ Email: bhambernal@gmail.com
}

\begin{abstract}
This research undertaking aimed to find out the impact of instructional technology in teaching Music. Specifically, it was framed from the following context: 1 . What is the mean performance of the controlled group and experimental group after the instructional technology was used in teaching Music?;2. What is the difference in the mean performance of the control group and experimental group after instructional technology was used in Teaching music? ;The researcher employed the experimental research method specifically the between-group design. From the results of the statistical computations, the following were revealed: The experimental group visibly performed better after instructional technology was integrated in teaching music than their control group counterpart. Findings of the study revealed there was a statistically significant differences in the academic achievement between the average mark of the experimental group students and the average mark of the control group students in favor of the experimental group.

Keywords: role of music; teaching music; academic achievement
\end{abstract}

\section{Introduction}

The distinct idea of education in this modern time has become broader and wider in scope. Education is no longer thought of as a pursuit of certain course of a study but regarded as life in itself. Education became a valuable engine for the growth and progress of oneself and society. It does not only imprint knowledge, skills and inculcates values, but is also responsible for building human capital which breeds, drives and sets technological innovation and economic growth. In today's era, information and knowledge stand out as very important and critical input for growth and survival. Rather than looking at education simply as ameans of achieving social upliftment, the society has to view education as an engine of advancement in an information era propelled by its wheels of knowledge and research leading to development (Damodharan and Rengarajan, 2018).

The global educational reforms has driven the academic institutions' administrators and teaching workforce to mainstream instructional technology within the realm of the educational process. Mainstreaming the technological media (popularly termed as Multimedia) within has led to infinite applications of computer technologies. The concept of this technology came into being with the appearance of sound cards, then compact disks, then came the use of digital camera, then the video or video clips which made computer an essential educational tool in a study conducted by Mariss (1980). The study aims at comparing the efficiency of the teacher's traditional explanation and the multimedia method in the students' academic achievement and their attitudes. The researcher used the experimental method and the study was conducted on a 


\section{Britain International of Linguistics, Arts and Education (BIoLAE) Journal \\ ISSN: 2685-4813 (Online), 2685-4805 (Print) \\ Vol.1, No. 2, November 2019, Page 94-100}

sample comprising 80 students of the ninth grade. The sampling is divided into two groups: one is control and the other is experimental. The researcher used diagrams, tapes and programed films as intervention of the study. The most important result was: that the academic achievement of the experimental group increases when the students used the multimedia. Allen (1998) conducted a study to find out the efficiency of multimedia software in the academic achievement of a sample from Texas University in the microorganism curriculum, their knowledge retention, and their attitudes toward using multimedia computers in teaching the microorganism course. The study sample comprised of 76 students, divided equally into two groups: control and experimental. The 16-week study result uncovered statistically-significant differences in the academic achievements, knowledge retention and attitude toward computer, in favor of the experimental group which studied using the multimedia method over the control group which studied using the traditional method. In a study conducted by Paderanga (2018) entitled, classroom video conferencing, its contribution to peace education, which examined the educational workability of using classroom video conferencing (CVC) as an instructional approach in teaching peace education in Iligan National High School, Philippines utilizes a quasiexperimental research design to compare the effect of CVC to the traditional approach of teaching peace education. Students in the CVC group were taught using video and audio transmissions, a technique heavily dependent on means of communication and technology. The findings of her study revealed that the CVC had a significant effect on students' posttest scores. The CVC group's performance in the pretest and posttest was highly different revealing that the treatment had significant effect on students' posttest scores. There was a difference between posttest academic performance of students taught with the traditional approach and those taught with CVC approach, in favor of the CVC group. With reference to respondents' relationship between their test scores and the instructional approach, the CVC approach was seen as a factor affecting the performance of the students.

In another study conducted by Carreon (2016) entitled enhancing the level of learning through video clips, some of the salient results revealed that the integration of video clips in Technology and Livelihood Education (TLE) topics enhance the students' level of understanding while the employment of traditional methods of teaching did otherwise and this strengthens the researcher's assumption that students learn better if video clips are integrated in teaching TLE.

Surry and Farquhar (1997) assert that increased awareness of diffusion's importance and expanded use of diffusion theories are of potentially great benefit to instructional technology in the field of music education (cited in Achola, 2007). In context, multimedia is significantly defined as the combination of various digital media types such as text, images, audio and video, into an integrated multi-sensory interactive application or presentation to convey information to an audience (Fouda, 2008). This research aimed to find out the impact of instructional technology in teaching Music. Specifically, it was framed from the following context: 1 . What is the mean performance of the controlled group and experimental group after the instructional technology was used in teaching music?; 2. What is the difference in the mean performance of the control group and experimental group after instructional technology was used in teaching music? Figure 1 reflects the conceptual scheme of this study which comprises of the independent and dependent variable. The independent variable, the mainstreaming of instructional technology in teaching music constitutes the cause of the study while the independent variable or the effect factor is the attainment of an improved academic performance by the Grade 7 students in the subject, Music. Based on the interrelationship of the variables, the expected outcome is to propose a guideline integrating innovation and technology in teaching music. 


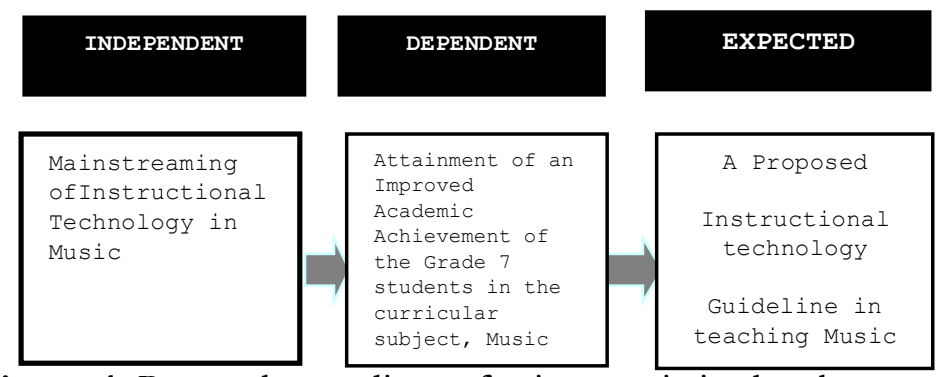

Figure 1. Research paradigm of using music in the classroom

\section{Research Method}

This study utilizes the experimental research method specifically the between-group design. The between-group design occurs with two groups; one is generally regarded as the treatment group, which receives the 'special' treatment, that is, the instructional technology in teaching Music; and the control group, which receives no variable treatment and is used as a reference. The controlled variables of the study where both group of respondents are equivalent or have in common are in terms of: academic level, class size, teacher and teaching location.

The respondents of the study were the Grade 7 students of Irisan National High School, Baguio City. One hundred (100) Grade 7 students were involved in this undertaking. Fifty (50) students were assigned as Class A or control group; and 50 students comprised the experimental group or Class B. Topics for instructional technologies include rhythm, tempo, harmony, dynamics, form, texture and melody, and classification of instruments.

Cluster sampling was utilized in the study which denotes that one (1) randomly selected class from four (4) Grade 7 classes were chosen as control group and one (1) class were selected as the experimental group. The experimental group was given the instructional technology in teaching music as the treatment of the study while the control group was held constant, meaning, traditional teaching method and strategies was upheld.

Table 1 reflects the frequency and percentage distribution of the respondents based on selection criterion by class assignment.

Table 1. Population based on Selection Criterion by Class Assignment

\begin{tabular}{lcc}
\hline Class & Frequency $(\mathrm{f})$ & Percentage $(\%)$ \\
\hline A - Control Group & 50 & 50 \\
B - Experimental Group & 50 & 50 \\
\hline TOTAL & 100 & 100.00 \\
\hline
\end{tabular}

The main data gathering tool that was used in the study was a teacher-made test. This test was used as leverage or gauge to affirm or negate the supposition of this study that instructional technology do in fact has an effect to the Grade 7 students' developmental modes of learning. The teacher-made test comprised of 40 design-specific items that is measurable and observable and in line with DepEd's Curriculum Guide series of 2016. The Table of Specification for one-week long lesson includes 
Table 2. Table of Specification for Music

\begin{tabular}{lcccccc}
\hline \multicolumn{1}{c}{ Topic } & $\begin{array}{c}\text { \# of } \\
\text { School } \\
\text { Days }\end{array}$ & $\begin{array}{c}\text { \# of } \\
\text { items }\end{array}$ & Knowledge & Skills & Application & Total \\
\hline $\begin{array}{l}\text { Elements of Music and } \\
\text { Instruments classification }\end{array}$ & 5 & 40 & 20 & 10 & 10 & 40 \\
\hline
\end{tabular}

This section involves the process preceding the collection of pertinent data in order to answer questions concerning the current status of the subject of the study.

Prior to the execution of the experimental session to two systematically and cautiously selected classes, a letter of permission was sought from the principal of Irisan National High School that the researcher may be allowed to conduct an experimental research utilizing instructional technology in teaching Music as an intervention of the study. After granting the permission the researcher pushed through with the week-long experimentation. To avert any extraneous occurrences to take place, the researcher personally conducted the experiment and administered the teacher-made test to target respondents and the results of the investigation were then statistically computed, tabulated and subjected to data analysis.

\section{Discussion}

From the results of the statistical computations, the following were revealed: The experimental group visibly performed better after instructional technology was integrated in teaching music than their control group counterpart. Findings of the study revealed there was a statistically significant differences in the academic achievement between the average mark of the experimental group students and the average mark of the control group students in favor of the experimental group.

This research endeavor therefore sheds light on the impact of integrating instructional technology in teaching music using two sets of respondents. These are the control group who were presented with traditional teaching method and the experimental group who benefitted with mainstreamed instructional technology. Reflected on table 3 is the mean performance of the two cluster-groups of respondents under two distinct experimental variables (the control and experimental). Running through the statistical results using the teacher-made test as benchmark, it was revealed that of the 40 items the experimental group obtained a mean performance of 34 or a whooping group proficiency level of eighty-five percent (85\%) academic achievement in music whilst their control group counterpart contributed a mean performance of 22 or fifty-five percent $(55 \%)$ achievement level and exhibited a mean difference of 12 or $30 \%$ percent.

Table 3. Mean Performance of the Variables under Study

\begin{tabular}{lcc}
\hline Experimental Variables & Mean & Std. Deviation \\
\hline $\begin{array}{l}\text { Control Group } \\
\text { (Traditional Teaching) }\end{array}$ & 22 & 6.24 \\
$\begin{array}{l}\text { Experimental Group } \\
\text { (Instructional Technology) }\end{array}$ & 34 & 3.74
\end{tabular}


Mean Difference $=12$

The experimental group visibly performed better that their control group counterpart after instructional technology was mainstreamed in teaching music. The result was further reinforced by the homogeneity and heterogeneity of the obtained standard deviation scores for both groups. It was worth noting that the achievement scores of the experimental group are highly compacted to the mean of 34 which connotes that the beneficiary of the instructional technology has collectively amassed test scores ranges from 30 to 38 which is an indicative that majority of the students retained the concepts taught in Music as opposed to the recipient of the traditional method whose test scores are slightly swayed above and below the mean of 22 . This is an obvious manifestation that the spread of scores of the control group are widely dispersed and heterogeneous since the bulk of their test scores ranged from 16 to 28 (which means that there is a presence of too high or too low scores).

The finding of the investigation implies that the delivery medium using "chalk and talk method" and teacher-centric instruction unleashed limited retention to students' learning. It can be highlighted from the preceding results that assimilation of instructional technology within the realm of the experimental group has positively increased the students' academic performance in Music compared to the results accrued by the control group, which could readily bear out a clear-cut generalization that utilization of multimedia in education is an effective gauge of achieving an improved and better learning outcomes for the students. Plethora of researches conformed to the result of the study and show that teaching with instructional technology pilots to considerably better learning and significantly better grades than teaching by mere conventional methods. Although most students in most of their studies believed that multimedia technology, such as video presentations of musical performances, could help students understand issues in music, and improve their musical performances, it is clear that electronic equipment allows students to engage in individual music learning and creation according to their own needs and ability, and at their own pace; and it can extend their access to information beyond that allowed by traditional classroom resources, thereby broadening the scope of their knowledge.

As a result, it could be asserted that the use of multimedia possesses the aim of helping students with different skills and learning styles. He also points out that multimedia provide the opportunity for every student to work individually. The subjects being taught could be transmitted to the students with web-based audio, visuals, video and animations in a way that could not be taught in classrooms authentically with other techniques. Also, multimedia eases education in terms of data used, storage, share and transportation of the visual and non visual written material, graphs, audios and other materials Moreover, multimedia creates a familiar, various, economic and practical environment in education.

Table 4 discloses the difference on the mean performance of the control and experimental group after instructional technology was used in teaching music.

Table 4. Difference on the Mean Performance of the Control and Experimental Group after Instructional Technology was used in Teaching Music

\begin{tabular}{lll}
\hline Experimental Variables & Mean & Std. Deviation \\
\hline $\begin{array}{l}\text { Control Group } \\
\text { (Traditional Teaching) }\end{array}$ & 22 & 3.74 \\
$\begin{array}{l}\text { Experimental Group } \\
\text { (Instructional Technology) }\end{array}$ & 34 & 6.24 \\
\hline
\end{tabular}




\begin{tabular}{lll}
\hline Mean Difference $=$ & 12 & \\
$\mathrm{t}-$ Stat $=$ & 11.66 & Decision: Significant \\
Sig. Level $=$ & .000 & \\
\hline
\end{tabular}

As shown in the table, there is a significant statistical variation in the mean performance of the experimental and the control group after instructional technology was used in teaching music. The computed t-value of 11.66 is numerically higher than the acceptance level $(\mathrm{p}<.000)$, which led to the rejection of the null hypothesis, which states that there is no significant difference in the mean performance of control group and experimental group after the use of instructional technology in teaching music.

The foregoing finding proves that amalgamating instructional technology in teaching music has positively and explicitly affects the students' academic success. It can also be safely surmised that the perceived higher performance of the experimental group could be readily explained by the fact that instructional technology set the tone to stimulate the imaginative dexterity of the students since it exemplified eclectic techniques and technological materials to encourage students to utilize all their senses other than their visual and hearing prowess.

The conventional method, on the other hand delimits the students to concretize abstract concepts which make their learning process more difficult. The finding of the study is parallel with the researches made by Lui Yui (2014), Şahin (2000), Akbaba (2009) and Coruk and Cakır (2015). Lui Yui (2014) made a notable conclusion that multimedia technology teaching means is one of the teaching means, which has effective role for music theory teaching and has incomparable advantage than traditional teaching means. Thus, using multimedia teaching to assist music theory teaching has become a common trend of university music education in China. To go over the results of the study, it can be observed that mainstreaming of instructional technology has greatly improved the performance of the experimental group students in the test than their control group counterpart who made use of traditional means in learning Music. When these variables were compared, it was worth noting that there is a significant statistical variation in the mean performance of the experimental and the control group after instructional technology was used in teaching music.

\section{Conclusion}

In agreement to the foregoing findings, the study highlighted the following conclusions: Students' academic success and retentive prowess were immensely improved by integrating instructional technology in teaching music. Teaching music through instructional technology was better than teaching music through conventional method. Based on the findings and conclusions, the following recommendations were drawn to elevate the multimedia know-how of the school, teachers and the administrators have to include in their in-service training and teachers' professional development, seminars and workshop on the utilization and integration of instructional technology into the mentors' educational practice. Students have to be immersed more and be fully involved into the learning process by enabling them to prepare some multimedia materials (power point, slides, internet searches, video clips, and animations) during their group classroom presentation for better retention and academic success in Music. 


\section{References}

Achola, M. (2007). The role of technology in music education: A survey of computer usage in secondarary schools in Nairobi province, Kenya. Retrieved from http://irlibrary.ku.ac.ke/bitstream/handle.

Allen, D. (1998). The effect of computer-based multimedia lecture presentation on comment college microbiology students achievement, attitudes and retention D.A.I., August, 448-A.

Carreon, L. (2016). Enhancing the level of learning through video clips. Unpublished Research Work presented to the Department of Education, Philippines.

Damodharan, V. and Rengarajan, V. (2018). Innovative methods of teaching. Retrieved from http://math.arizona.edu. Date of Retrieval, June 28, 2018.

Fouda, O. (2008). Computer uses in education, third edition.

Mayer, R. (2005). The cambridge handbook of multimedia learning. New York: Cambridge University Press.

Paderanga, L. (2018). Classroom video conferencing: Its contribution to peace education. Retrieved from https://www.sciencedirect.com. Date of Retrieval June 